\title{
Lectotypification of three names in Garcinia (Garciniaceae)
}

\author{
Shameer P. S. \& N. Mohanan* \\ Jawaharlal Nehru Tropical Botanic Garden and Research Institute, Palode, Thiruvananthapuram - 695562, Kerala, India. \\ *E-mail: nmohanan59@gmail.com
}

\begin{abstract}
Lectotypes are designated for three names in Garcinia namely, G. andamanica King, G. anomala Planch. \& Triana and G. calycina Kurz.
\end{abstract}

Keywords: Clusiaceae, Lectotype.

\section{Introduction}

Garcinia L., the second largest genus within the family Clusiaceae, includes nearly 260 species worldwide (Mabberley, 2017). The centre of diversity of the genus is considered to be the Malesian region, with some species reaching India and the Micronesian Islands, and further extends to tropical Africa and the Neotropics (Jones, 1980; Nazre, 2006; Rogers \& Sweeny, 2007; Stevens, 2007; Sharma et al., 2013).

The genus was revised for India by Maheshwari (1964) and Singh (1993) who reported 31 and 35 species respectively. During a recent taxonomic revision of the genus in India, the authors found three names of Garcinia without proper typification. Hence lectotypes are designated here for these names as per Shenzhen code (Turland et al., 2018).

\section{Typification}

Garcinia andamanica King, J. Asiat. Soc. Bengal, Pt. 2, Nat. Hist. 59(2): 170, t. 160. 1890. Lectotype (designated here): INDIA, Andaman Islands, 1884, King's Coll. 224 (CAL46765!)

Fig. 1

Notes: King (1890) described G. andamanica referring to three gatherings (Helfer 872, Kurz s.n., and King's Coll. 224) and according to Art. 9.6 of Shenzhen code (Turland et al., 2018), they constitute syntypes. Authors could trace the specimens collected by Kurz (CAL46958) and King's Coll. 224 (CAL46765) at CAL, but could not locate Helfer 872 at CAL or in any other herbaria.

Received: 09.08.2018; Revised \& Accepted: 24.03.2019

Published Online: 30.06.2019
The specimen collected by King's Collector (CAL 46765) is well preserved and completely agrees with the protologue. Hence it is designated here as the lectotype, in accordance to Art. 9.3 and 9.12 of ICN (Turland et al., 2018).

Garcinia anomala Planch. \& Trian., Ann. Sci. Nat. Bot. sér. 4, 14: 329. 1860. Lectotype (designated here): INDIA, East Bengal, s.d., Griffith 848 (G00458432 digital image!; isolectotype CAL46566!, W0073367 digital image!) Fig. 2

Notes: Garcinia anomala was described by Planchon and Triana (1860), based on specimens collected from

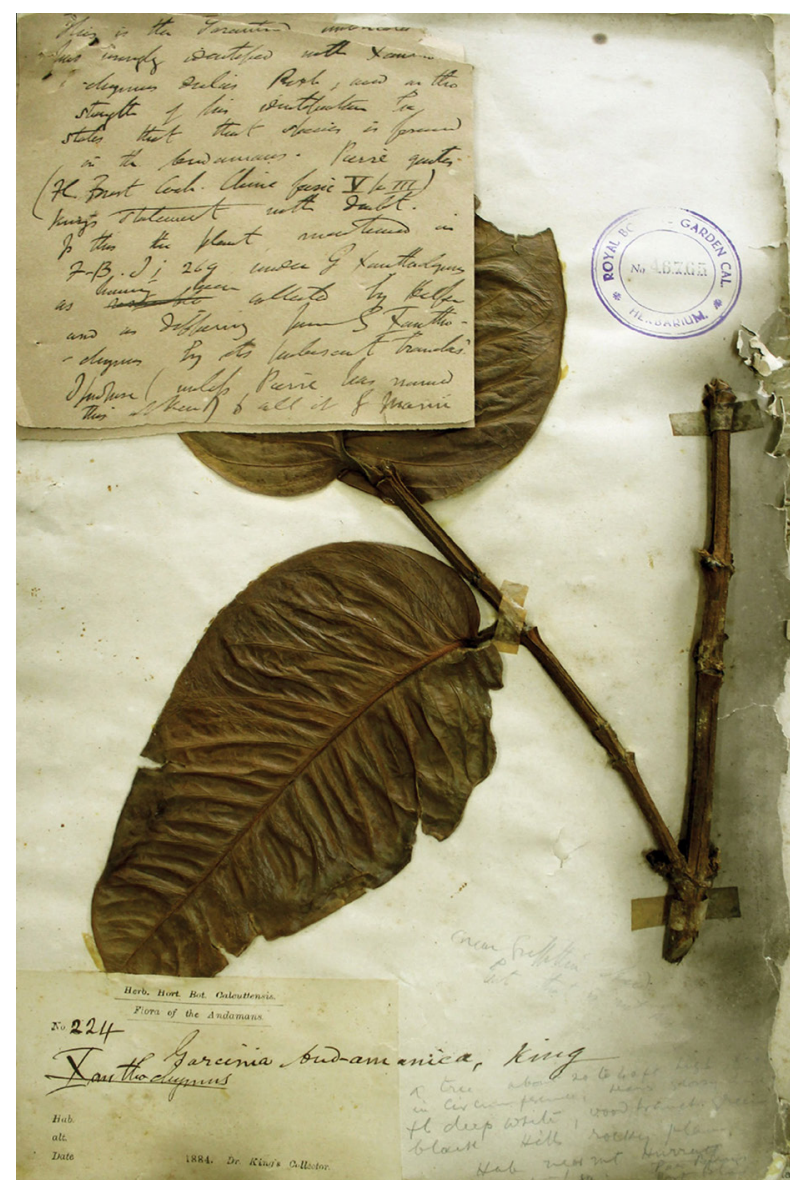

Fig. 1. Lectotype of Garcinia andamanica King (King's Coll. 224, CAL46765) (c) The Director, Botanical Survey of India, Kolkata, reproduced with the permission. 
"Khasya" (Griffith 848) and Assam (Hooker \& Thomson 14). Authors traced original materials of Griffith (CAL46566, G00458432, W0073367) and Hooker \& Thomson (CAL, K000380443, K000677605, W18890318023, W18890318024, W18890318030, W0073366) in various herbaria. Among them, G00458432 is designated here as the lectotype, in accordance with Arts. 9.3 and 9.12 of the ICN.

Garcinia calycina Kurz, J. Bot. 13: 324. 1875. Lectotype (designated here): INDIA, Nicobar Islands, Kamorta, 02.1875, S. Kurz s.n. (CAL0000005868!).

Fig. 3

Notes: Garcinia calycina was described by Kurz (1875) from Kamorta, but no specimens were cited in the protologue. Specimens collected by Kurz (Kamorta), without collection numbers were found at CAL (CAL0000005868) and at K (K0006776343). Among them the complete and well preserved specimen, CAL0000005868 is designated here as lectotype, in accordance to Art. 9.3 and 9.12 of ICN.

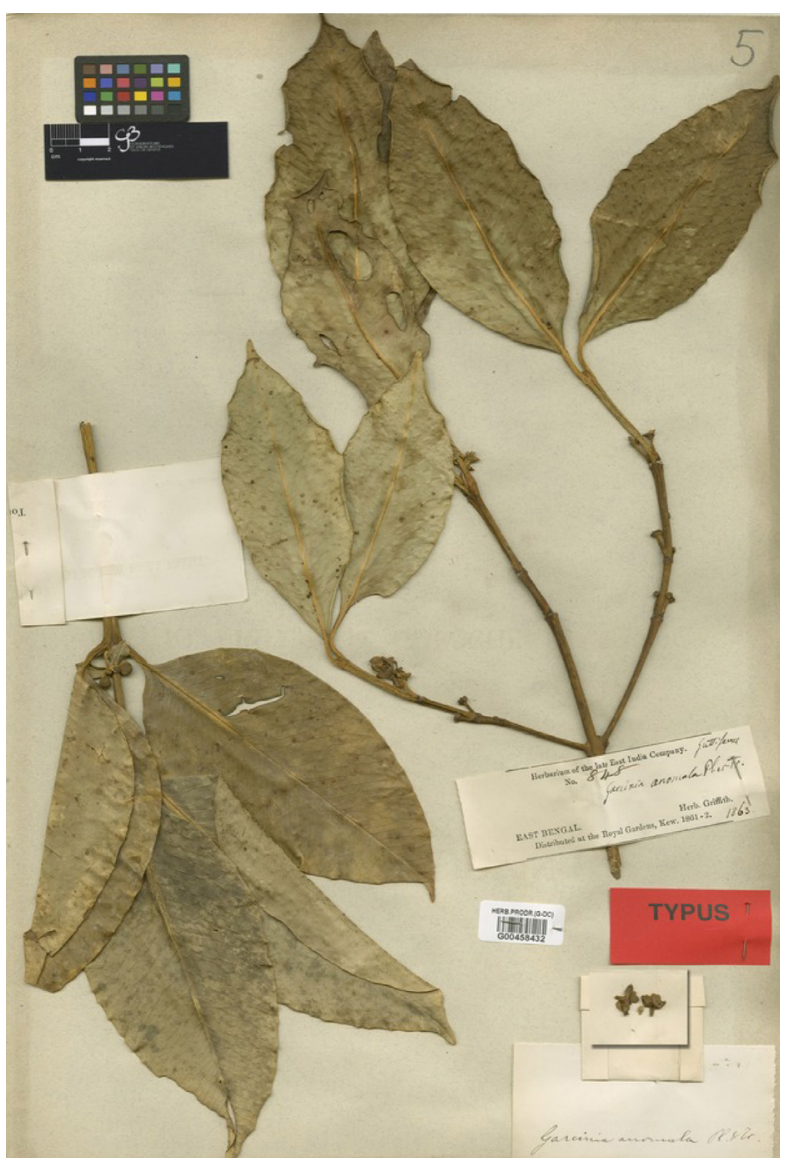

Fig. 2. Lectotype of Garcinia anomala Planch. \& Trian. (Griffith 848, G00458432 image!) (C) Conservatoire et Jardin botaniques de la ville de Geneve)

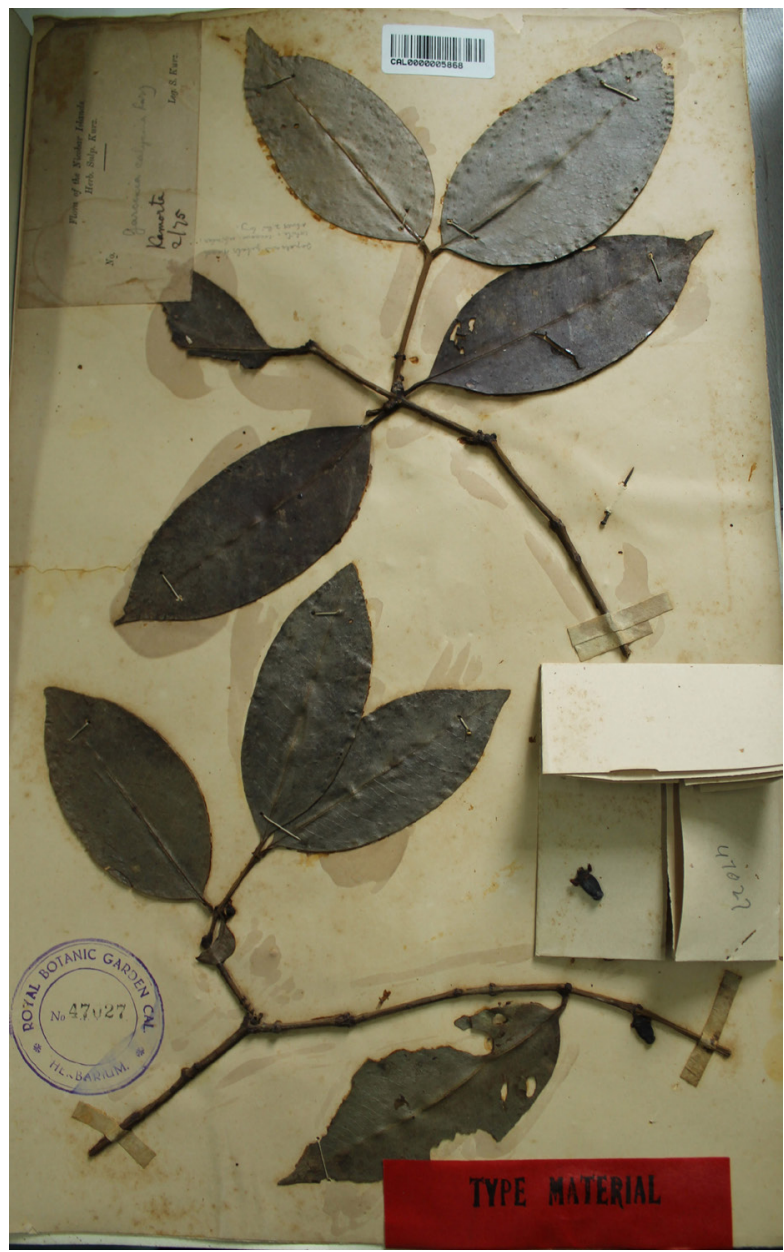

Fig. 3. Lectotype of Garcinia calycina Kurz (S. Kurz s.n., CAL0000005868) (C The Director, Botanical Survey of India, Kolkata, reproduced with the permission.

\section{Acknowledgements}

Authors are grateful to the authorities of CAL, TBGT, MH, BM, BR, G, K, P and W for permission to access collections/images of types; Dr. K. N. Gandhi (Harvard University) and Dr. Subir Bandopadhyay, (CNH, Kolkata) for nomenclatural discussion. Head of Office, Central National Herbarium, Botanical Survey of India, Howrah is thankfully acknowledged for giving copyright permission for using the images from $\mathrm{CNH}$.

\section{Literature Cited}

JONES S.W. 1980. Morphology and major taxonomy of Garcinia (Guttiferae). Ph.D. Thesis. London: University of Leicester and British Museum (unpublished).

KING G. 1890. Materials for a flora of the Malay Peninsula. Journal of the Asiatic Society of Bengal (Part 2), Natural Science 59(1): 113-172. 
KURZ S. 1875. Descriptions of new plants from the Nicobar Islands (including a few from Andaman Islands). Journal of Botany 13: 321-333.

MABBERLEY D. 2017. Mabberley's Plant-book: A portable dictionary of plants, their classification and uses. Cambridge University Press. Cambridge.

MAHESHWARI J.K. 1964. Taxonomic study of Indian Guttiferae III. The genus Garcinia L. s.l. Bulletin of the Botanical Survey of India 6: 107-135.

NAZRE M. 2006. Taxonomic revision and molecular studies of Garcinia section Garcinia (Guttiferae). Ph.D. dissertation, University of Edinburgh (unpublished).

PLANCHON J.E. \& J. TRIANA 1860. Mémoire sur la famille des Guttiferes. Annales des Science Naturelles Botanique (Series 4) 14: 226-367.

ROGERS S.Z. \& P.W. SWEENEY 2007. Two distinctive new species of Malagasy Garcinia (Clusiaceae). Systematic Botany 32: 772-779.

SHARMA B.P.H., HANDIQUE P.J. \& H.S. DEVI 2013.
A historical and taxonomic overview of Garcinia L. and its reproductive ecology. Folia Malaysiana 14(1): 63-76.

SINGH N.P. 1993. Clusiaceae. In: SHARMA B.D. \& M. SANJAPPA (eds.), Flora of India. Volume 3. Botanical Survey of India, Kolkata. pp. 98-131.

STEVENS P. 2007. Clusiaceae- Guttiferae. In: KUBITZKI K. (ed.), The families \& genera of vascular plants. Volume 9. Flowering Plants Eudicots, Springer Verlag, Berlin. pp. 48-66.

TURLAND N.J., WIERSEMA J.H., BARRIE F.R., GREUTER W., HAWKSWORTH D.L., HERENDEEN P.S., KNAPP S., KUSBER W.H., LI D.Z., MARHOLD K., MAY T.W., MCNEILL J., MONRO A.M., PRADO J., PRICE M. J. \& G.F. SMITH (eds.) 2018: International Code of Nomenclature for algae, fungi, and plants (Shenzhen Code) adopted by the Nineteenth International Botanical Congress Shenzhen, China, July 2017. Regnum Vegetabile 159. Glashütten: Koeltz Botanical Books. DOI https://doi.org/10.12705/ Code.2018. 